\title{
Discovering learning model analysis to improve learning results of social science for elementary school
}

\author{
Esti Setiawati, Post Graduate Program, Universitas PGRI Yogyakarta, Indonesia, esti@upy.ac.id, ORCID: \\ 0000-0003-0365-0984 \\ Istiningsih, Faculty of Tarbiyah and Education, Universitas Islam Negeri Sunan Kalijaga, Indonesia, \\ istiningsih81@gmail.com, ORCID: 0000-0002-1751-0299 \\ Marti Widya Sari, Faculty of Science and Technology, Universitas PGRI Yogyakarta, Indonesia, \\ widya@upy.ac.id, ORCID: 0000-0003-4462-5259
}

\begin{abstract}
Discovery learning sets the students free to study and learn based on the preferred learning styles, to gain competencies and fulfill the curiosities. Teachers are expected to create circumstance in which students may solve problems by providing the consultation when it is needed. This study aimed to re-analyze the implementation of discovery learning models on improving social studies learning outcomes of students of basic education. This research uses a descriptive approach with meta-analysis method. The study begins by formulating a research problem, followed by searching relevant research results for analysis. Research data collection is done by searching in an electronic journal through Google Scholar and searching thesis documents in the study program library. Based on the results of the analysis, it shows that the discovery learning model can improve social studies learning outcomes from the lowest $4.95 \%$ to the highest $47.86 \%$ with an average index of $19.56 \%$.
\end{abstract}

Keywords: Meta analysis, discovery learning model, social studies, learning outcomes Received: 20.11.2020 $\quad$ Accepted: 10.12.2020 $\quad$ Published: 12.01.2021

\section{INTRODUCTION}

The fundamental and crucial problem in the world of education is the low quality of education, one of reasons is the teachers who have not done things optimally (Magyar, Krausz, \& Hab, 2020). This is shown by the data of UNESCO in Global Education Monitoring (GENT) Report in 2016. It reveals fact that the Indonesian's quality of education is number 10 out of 14 of the developing countries. This becomes worse since the quality of Indonesian's teachers is number 14 out of 14 developing countries. This condition reveals us the Indonesian's quality of education is far from good.

The struggles to increase the quality of education have been conducted by our government as the policy maker (Ural, 2009). However, there are still overlaps on field related to the education quality (Didham \& Ofei-manu, 2020). Research which explained that the overlapping exists although the school is the pilot project of educational decentralization. It needs to formulate the educational policies that meet the today's needs as a way to increase the education qualities (Garira, 2020). For example, the teaching material should be completed with the multi-media and the additional preparation for the teachers, to make it possible for them to conduct the multi-media based learning (Sari, Firat, \& Karaduman, 2016).

Another policy that should be considered by our government and the stake holders is the intensive substantial learning subjects training for our teachers, including the use of effective multimedia as the supporting tools (Bazhenov, Bazhenova, Khilchenko, \& Romanova, 2015). Besides, the intensive training is not less important than the pedagogical competencies and the curriculum (Sirotová, 2016). In relation to that, in accordance with the developing of education quality, the process of teacher's learning and studying is expected that the students may gain the better learning outcomes or results (Guo, Saab, Post, \& Admiraal, 2020). The learning interaction may run well and effective if it is supported by some components such as the effective curriculum, sufficient facilities and infrastructure, the proper learning model, fun learning to make the students actively join the learning process (Alten, Phielix, Janssen, \& Kester, 2019).

Some research findings claimed that the science learning outcomes increase since the teachers apply the discovery learning (Rubio-alcalá et al., 2019). This learning model develops the concept which is scientific, relevant, sufficient, actual and contextual, flexible complete, systematic and consistent (Verstege, Pijeira-díaz, Noroozi, Biemans, \& Diederen, 2019). The model of discovery learning employs five components of learning strategy, those are the modeling, asking, inquiring, learning community and assessing based on portfolio (Murtonen, Gruber, \& Lehtinen, 2017). Teachers have got used to on the 
model of discovery learning (Iss, Atoche-rodríguez, Salazar-pastrana, \& Durán-pérez, 2017). Discovery learning is a method to understand the concept, meaning and relation through the process of intuiting which ends on drawing the conclusion (Verstege et al., 2019).

The model of discovery learning is the learning strategy which requires students to conduct observation, experiment or scientific acts to draw conclusion from the act of scientific which has been conducted (Almeida \& Cunha, 2020). Through this model, students are asked to find by themselves about what have been learnt, then construct the knowledge to get the meaning. Teachers are the facilitators providing supports and facilitating the students' learning process and experience (Trepule, Tereseviciene, \& Rutkiene, 2015). The main characteristics of discovering learning are: 1) exploring and solving the problems to create, merge and generalize the knowledge; 2) students-centered, and 3) merging the new existing knowledge.

Discovery learning sets the students free to study and learn based on the preferred learning styles, to gain competencies and fulfill the curiosities. Teachers are expected to create circumstance in which students may solve problems by providing the consultation when it is needed. Teachers' duty is as the guide or tutor, giving suggestions when it is needed by the students, including feedback in the proper time.

Some benefits of employing the discovery learning are: 1) increase the students' intellectual potentiality; 2) move the reward from extrinsic to intrinsic; 3) conduct the complete learning through finding; and 4) used as the tool to train students' memory. Teachers and students are benefited from this learning process since it involves both parties in the process to find and construct a new knowledge or science (Reich, Collins, \& Defranco, 2016).

Related to the model of Discovery Learning, both teachers and students expect improvement of the students' learning results. Naturally, this model requires students to increase motivation since the nowadays learning outcomes require students to take participation (Stockwell, Stockwell, Cennamo, \& Jiang, 2015). The learning outcome is the main purpose of the learning activity and also the topmost of the learning successfulness that has been set. The outcome can be the cognitive aspect (knowledge), affective (attitude/behavior), or psychomotor (skill). The outcomes are influenced by the students' experiences on physical world and the surroundings. It depends on what have been known or revealed, such as concepts, purposes and motivation that influence interaction with the learning material or what would be studied or learnt (Guo et al., 2020).

In accordance with the above explanation or idea, researcher claimed his idea that the learning outcome is not limited to the result of the etst, it has the broader meaning. The outcome can be seen from : 1) students' change on attitude; 2) students' change on thinking pattern; 3) the new concept building. The success of the learning is influenced by various factors, curriculum, facilities and infrastructure, learning media, learning circumstance, or even the learning model that is used by the teachers (Reich et al., 2016). Universally, there are internal and external factors which influence the learning successfulness. The internal one is related to biological and psychological factors of the students.

The students' biological factor is related to the health physical condition which functions well. This condition gives chance to students to gain good learning result or outcome (Birchler \& Michaelowa, 2016). The psychological factor is related to the positive mental behavior, intelligence, aptitude, memory and concentration. If the psychological factors run well, the learning result would be positively affected. Meanwhile, the students' external factors come from the outside elements such as the condition of family, school, society and also the provided or available time. This external one has big share for the success of the learning process. The environment of family, school, society and the conducive time give the great contribution to the development of learning outcome (Zendler \& Greiner, 2020).

One interesting thing in this meta-analysis is that the Discovery Learning is applied to the learning of social science, not to natural science or Math. It is commonly found that those two kinds of subjects, which focused on finding new knowledge, employ this learning model (Rold, 2020). Based on that explanation, the focus of this research is whether the implementation of Discovery Learning can improve the learning results of social science learning if it is applied in some different schools? The objective of this study is to re-analyze the implementation of discovery learning models on improving social studies learning outcomes of students of basic education.

\section{METHOD}

This is a descriptive research which employs meta-analysis, that is the research method by summarizing, reviewing and analyzing the research data from some of existing research findings. This research's data gaining is by searching in google scholar and documenting research theses in the study programs. The keywords that were used during the searching process are discovering learning, learning result and social 
science learning. The searching process is resulted on the shared common 27 research articles and three theses. The six online relevant articles were picked up and one theses which is relevant to the context of the research. The basic assumption to choose those papers is the availability of data before and after the implementation in form of score, then it is analyzed quantitatively and qualitatively descriptive.

\section{RESULTS AND DISCUSSION}

The research findings attached to this meta analysis research are as follows:

1. The application of the discovery learning to improve the result of social science learning in the elementary school by Ina Azaria Yupita and Waspodo Tjipto S.

2. Improving social science learning result through the strategy of inquiry discovery learning for the fourth graders of North Cikarang District public elementary school of Bekasi by Siti Masitoh.

3. The implementation of discovery learning equipped with visual media to improve social science learning by I Dewa Ayu ratna Dewi and Ni Wayan Arini.

4. The influence of Discovery Learning implementation towards the students' learning result on Social Science of the Fourth Graders by Agustin Anindah and Suprayitno.

5. The influence of discovery learning implementation towards the elarning results of social science of the fourth graders of elementary school by Firosalia Kristin and Dwi Rahayu.

6. Improving the meta cognitive awareness and learning result through the implementation of discovery learning on the social science learning by Ari Hastati and Erwin Nurdiansyah.

7. The difference on learning attitude, learning motivation and learning achievement of Social Science using Discovery Learning and Conventional Model on the Fifth Graders in Melati Cluster Sub-District of Banyu Urip Purworejo in the first Semester academic Year of 2019/2020. The thesis of Endang Titik Lestari.

The existing of research data are many and broad, they need to be processed further to get the essential things. The next step, the research data would be analyzed and reported quantitatively and qualitatively describe. The Table 1 below is the result of data analysis related to the discovery learning model.

Table 1. The analysis result of Discovery Learning Model implementation

\begin{tabular}{|l|l|l|l|l|l|l|}
\hline & Research Title & Research Type & Improved Learning Outcomes \\
\cline { 4 - 7 } & & & Before & After & Gain & $\begin{array}{l}\text { Gain } \\
\text { (\%) }\end{array}$ \\
\hline 1 & $\begin{array}{l}\text { The application of the discovery learning to } \\
\text { improve the result of social science learning in the } \\
\text { elementary school by Ina Azaria Yupita and } \\
\text { Waspodo Tjipto S. }\end{array}$ & $\begin{array}{l}\text { Classroom Act } \\
\text { Research }\end{array}$ & 63,87 & 94,44 & 30,57 & 47,86 \\
\hline 2 & $\begin{array}{l}\text { Improving social science learning result through } \\
\text { the strategy of inquiry discovery learning for the } \\
\text { fourth graders of North Cikarang District public } \\
\text { elementary school of Bekasi by Siti Masitoh. }\end{array}$ & $\begin{array}{l}\text { Classroom Act } \\
\text { Research }\end{array}$ & 64,00 & 75,00 & 11,00 & 17,18 \\
\hline 3 & $\begin{array}{l}\text { The implementation of discovery learning } \\
\text { equipped with visual media to improve social } \\
\text { science learning by I Dewa Ayu ratna Dewi and Ni } \\
\text { Wayan Arini. }\end{array}$ & $\begin{array}{l}\text { Classroom Act } \\
\text { Research }\end{array}$ & 82,36 & 86,44 & 4,08 & 4,95 \\
\hline 4 & $\begin{array}{l}\text { The influence of Discovery Learning } \\
\text { implementation towards the students' learning } \\
\text { result on Social Science of the Fourth Graders by } \\
\text { Agustin Anindah and Suprayitno. }\end{array}$ & $\begin{array}{l}\text { Quasi } \\
\text { eksperiment }\end{array}$ & 77,83 & 84,83 & 7,00 & 8,99 \\
\hline 5 & $\begin{array}{l}\text { The influence of discovery learning } \\
\text { implementation towards the elarning results of } \\
\text { social science of the fourth graders of elementary } \\
\text { school by Firosalia Kristin and Dwi Rahayu. }\end{array}$ & $\begin{array}{l}\text { Quasi } \\
\text { Experimental } \\
\text { Design }\end{array}$ & 70,22 & 82,08 & 11,86 & 16,88 \\
\hline 6 & $\begin{array}{l}\text { Improving the meta cognitive awareness and } \\
\text { Implassroom Act }\end{array}$ & 75 & 92,59 & 17,59 & 23,45 \\
\hline
\end{tabular}




\begin{tabular}{|c|c|c|c|c|c|c|}
\hline & \multirow{2}{*}{ Research Title } & \multirow{2}{*}{ Research Type } & \multicolumn{4}{|c|}{ Improved Learning Outcomes } \\
\hline & & & Before & After & Gain & $\begin{array}{l}\text { Gain } \\
(\%)\end{array}$ \\
\hline & $\begin{array}{l}\text { learning result through the implementation of } \\
\text { discovery learning on the social science learning } \\
\text { by Ari Hastati and Erwin Nurdiansyah. }\end{array}$ & Research & & & & \\
\hline 7 & $\begin{array}{l}\text { The difference on learning attitude, learning } \\
\text { motivation and learning achievement of Social } \\
\text { Science using Discovery Learning and } \\
\text { Conventional Model on the Fifth Graders in } \\
\text { Melati Cluster Sub-District of Banyu Urip } \\
\text { Purworejo in the first Semester academic Year of } \\
\text { 2019/2020. The thesis of Endang Titik Lestari. }\end{array}$ & $\begin{array}{l}\text { Descriptive } \\
\text { Comparative }\end{array}$ & 70,62 & 83,10 & 12,48 & 17,67 \\
\hline \multicolumn{3}{|c|}{ Discovery Learning Model } & 71,98 & 85,49 & 13,51 & 19,56 \\
\hline
\end{tabular}

Based on the research data analysis, it indicates that discovery learning model can improve the social science learning results, starting from $4,95 \%$ as the lowest until $47,86 \%$ as the highest with the mean of $19,56 \%$. The analysis result in Table 2 reveals us that social science learning result by employing discovery learning improves better with the starting mean of 72,11 to 85,49. Table 3 describes us the relationship among mean scores, befre and after implementing the Discovery Learning.

The highest test result, $\mathrm{Ho}=$ there is no significant difference on social science learning result before and after implementing the discovery learning, and $\mathrm{H} 1=$ there is significant different on social science learning result before and after implementing the discovery learning. Table 4 describes us that the value $t_{\text {count }}=-4.015<t_{\text {table }}=2.447$, then Ho is rejected. It can be inferred that there is significant difference on social science learning result before and after implementing the discovery learning.

Tabel 2. Paired Samples Statistics

\begin{tabular}{|l|l|l|l|l|l|}
\hline \multicolumn{5}{|c|}{ Paired Samples Statistics } \\
\hline & & Mean & N & Std. Deviation & Std. Error Mean \\
\hline \multirow{2}{*}{$\begin{array}{l}\text { Pai } \\
\text { r } 1\end{array}$} & Before & 72.1143 & 7 & 7.12805 & 2.69415 \\
\cline { 2 - 6 } & After & 85.4971 & 7 & 6.57306 & 2.48438 \\
\hline
\end{tabular}

Tabel 3. Paired Samples Correlations

\begin{tabular}{|l|l|l|l|l|}
\hline \multicolumn{4}{|c|}{ Paired Samples Correlations } \\
\hline & & $\mathrm{N}$ & Correlation & Sig. \\
\hline Pair 1 & Before \& After & 7 & .173 & .710 \\
\hline
\end{tabular}

Tabel 4. Paired Samples Test

\begin{tabular}{|c|c|c|c|c|c|c|c|c|c|}
\hline \multicolumn{10}{|c|}{ Paired Samples Test } \\
\hline & & \multicolumn{5}{|c|}{ Paired Differences } & \multirow[t]{3}{*}{$\mathrm{t}$} & \multirow[t]{3}{*}{$\mathrm{df}$} & \multirow{3}{*}{$\begin{array}{l}\text { Sig. (2- } \\
\text { tailed) }\end{array}$} \\
\hline & & \multirow[t]{2}{*}{ Mean } & \multirow[t]{2}{*}{$\begin{array}{l}\text { Std. } \\
\text { Deviation }\end{array}$} & \multirow[t]{2}{*}{$\begin{array}{l}\text { Std. Error } \\
\text { Mean }\end{array}$} & \multicolumn{2}{|c|}{$\begin{array}{l}\text { 95\% Confidence Interval } \\
\text { of the Difference }\end{array}$} & & & \\
\hline & & & & & Lower & Upper & & & \\
\hline $\begin{array}{l}\text { Pair } \\
1\end{array}$ & $\begin{array}{l}\text { Before - } \\
\text { After }\end{array}$ & $\begin{array}{l}-33829 \mathrm{E} 1 \\
\end{array}$ & 8.81995 & 3.33363 & -21.53995 & -5.22576 & $\begin{array}{l}- \\
4.015\end{array}$ & 6 & .007 \\
\hline
\end{tabular}

Based on the research analysis and finding, it reveals fact that the implementation of discovery learning from each research with different approach can improve students' social science learning results although the result itself might be different through different approaches. This is caused by various factors, internal and external of the students. The discovery learning is beneficial for improving students' intellectual potentiality.

The result of Meta-Analysis that conducted by the researcher, it is analyzed that the internal and external factors give influence the existence of different result of those research. The different school condition, different students' proficiencies, different students' health condition, different implementation 
of the curriculum will give different impact on students' learning achievement. Besides, the teachers implementation of the same learning model will have possibly different results.

\section{CONCLUSIONS}

The implementation of Discovery Learning model has been conducted by employing various research approaches or methodologies. The result of meta analysis reveals us that the model of Discovery Learning will improve the social science elearning result in the elementary level, from $4,95 \%$ as the lowest to $47,86 \%$ as the highest with the mean index of $19,56 \%$. It is suggested that the further research would employ the more various and in-depth research articles and theses to get the more in-depth analysis and results.

\section{ACKNOWLEDGEMENT}

This research and publication is supported by The International Reputable Journal Acceleration (AJIB) and The Institute of Research and Community Services (LPPM) Universitas PGRI Yogyakarta.

\section{REFERENCES}

Almeida, L., \& Cunha, A. (2020). An integrative debate on learning styles and the learning process. Social Sciences \& Humanities Open, 2(1), 100017.

Alten, D. C. D. Van, Phielix, C., Janssen, J., \& Kester, L. (2019). Effects of flipping the classroom on learning outcomes and satisfaction: A meta-analysis. Educational Research Review Journal, 28(November 2018), 1-18.

Bazhenov, R., Bazhenova, N., Khilchenko, L., \& Romanova, M. (2015). Components of Education Quality Monitoring : Problems and Prospects, 214(June), 103-111.

Birchler, K., \& Michaelowa, K. (2016). International Journal of Educational Development Making aid work for education in developing countries: An analysis of aid effectiveness for primary education coverage and quality. International Journal of Educational Development, 48, 37-52.

Didham, R. J., \& Ofei-manu, P. (2020). Adaptive capacity as an educational goal to advance policy for integrating DRR into quality education for sustainable development. International Journal of Disaster Risk Reduction, 47(May 2019), 101631.

Garira, E. (2020). Needs assessment for the development of educational interventions to improve quality of education: A case of Zimbabwean primary schools. Social Sciences \& Humanities Open, 2(1), 100020.

Guo, P., Saab, N., Post, L. S., \& Admiraal, W. (2020). A review of project-based learning in higher education: Student outcomes and measures. International Journal of Educational Research, 102(April), 101586.

Iss, S., Atoche-rodríguez, K. E., Salazar-pastrana, A., \& Durán-pérez, A. M. (2017). Principals reconstructing their professional performance in elementary education : A participatory contribution within the educational system in. Journal of Behavior, Health \&amp; Social Issues, 8(1), 17-25.

Magyar, A., Krausz, A., \& Hab, A. (2020). Exploring Hungarian teachers ' perceptions of inclusive education of SEN students. Heliyon, 6(March).

Murtonen, M., Gruber, H., \& Lehtinen, E. (2017). The return of behaviourist epistemology : A review of learning outcomes studies. Educational Research Review, 22, 114-128.

Reich, A. Z., Collins, G. R., \& Defranco, A. L. (2016). Leisure , Sport \& Tourism Education Is the road to effective assessment of learning outcomes paved with good intentions? Understanding the roadblocks to improving hospitality education. Journal of Hospitality, Leisure, Sport \& Tourism Education, 18, 21-32.

Rold, D. (2020). Impact of different interaction protocols on group communication, satisfaction and learning outcomes of primary school children when using multitouch tabletops, 152 (March).

Rubio-alcalá, F. D., Arco-tirado, J. L., Fernández-martín, F. D., López-lechuga, R., Barrios, E., \& Pavónvázquez, V. (2019). A systematic review on evidences supporting quality indicators of bilingual , plurilingual and multilingual programs in higher education. Educational Research Review, 27(August 2018), 191-204.

Sari, A., Firat, A., \& Karaduman, A. (2016). Quality Assurance Issues in Higher Education Sectors of Developing Countries ; Case of Northern Cyprus. Procedia - Social and Behavioral Sciences, 229, 326334.

Sirotová, M. (2016). Pedagogical praxis as a process of developing professional competencies in 
university education of future teachers. Procedia - Social and Behavioral Sciences, 228(June), 529534.

Stockwell, B. R., Stockwell, M. S., Cennamo, M., \& Jiang, E. (2015). Blended Learning Improves Science Education. Cell, 162(5), 933-936.

Trepule, E., Tereseviciene, M., \& Rutkiene, A. (2015). Didactic Approach Of Introducing Technology Enhanced Learning ( TEL ) Curriculum In Higher Education. Procedia - Social and Behavioral Sciences, 191, 848-852.

Ural, A. (2009). Good elementary education. Procedia Social and Behavioral Sciences, 1(1), 1249-1254.

Verstege, S., Pijeira-díaz, H. J., Noroozi, O., Biemans, H., \& Diederen, J. (2019). Computers in Human Behavior Relations between students ' perceived levels of self-regulation and their corresponding learning behavior and outcomes in a virtual experiment environment. Computers in Human Behavior, 100(February), 325-334.

Zendler, A., \& Greiner, H. (2020). Education for Chemical Engineers The effect of two instructional methods on learning outcome in chemistry education: The experiment method and computer simulation. Education for Chemical Engineers, 30, 9-19. 